International Journal of Environment, Agriculture and Biotechnology
Vol-6, Issue-1; Jan-Feb, 2021
Jusnal Home Page Available: $\underline{\text { https://ijeab.com/ }}$ Journal DOI: $10.22161 /$ ijeab

\title{
Transfusion Transmissible Infections among Voluntary Blood Donors in Port-Harcourt Metropolis, Rivers State, Nigeria
}

\author{
Okafor, A.C. ${ }^{1}$, Dan-Jumbo A. ${ }^{2}$, Omunakwe, H.E. ${ }^{3}$, and Lawson, S.D. ${ }^{1}$
}

${ }^{1}$ Department of Medical Microbiology and Parasitology, Rivers State University, Nkpolu-Oroworukwo, Port-Harcourt, Nigeria.

${ }^{2}$ Infectious Disease Unit, Rivers State University Teaching Hospital, Port-Harcourt, Nigeria.

${ }^{3}$ Hematology Department, Rivers State University Teaching Hospital, Port-Harcourt, Nigeria.

Received: 28 Oct 2020; Received in revised form: 28 Jan 2021; Accepted: 22 Feb 2021; Available online: 28 Feb 2021

(C)2021 The Author(s). Published by Infogain Publication. This is an open access article under the CC BY license

(https://creativecommons.org/licenses/by/4.0/).

\begin{abstract}
A survey of Blood Transfusion Transmissible Infections (TTIs) among voluntary blood donors of different age groups was conducted between March 2017 and June 2018in Port-Harcourt metropolis, Rivers State, Nigeria. A total of 200 voluntary blood donors consisting of 151(75.5\%) males and 49(24.5\%) females participated in the study. All the blood donors were within the ages of 18 to 65 years. Blood samples were taken from the veins of blood donors. The blood samples were screened in the laboratory for Venereal Diseases (VD), Hepatitis B surface antigen (HBsAg), Hepatitis C Virus (HCV) and Human Immuno-deficiency Virus (HIV) 1 and 2 using test Kits. Of the 200 blood donors involved, none was positive for HIV 1 and 2 infections. Only 2(1\%) participants were positive for VDRL infections. A total of $8(4.0 \%)$ of the study participants were positive for HBsAg while $1(0.5 \%)$ was positive for $H C V$. The prevalence of TTIs was higher in females $6(3.0 \%)$ than in males 5(2.5\%), butthere was no significant differences in prevalence among genders $(P>0.05)$. Blood is still one of the main sources of transmission of Hepatitis $B$ Virus $(H B V), H C V$ and VD. Availability of safe blood for transfusion is necessary for the recuperation of the recipient. This can be achieved by vigorous screening of donors and donated bloods.
\end{abstract}

Keywords - Transfusion, Infections, Blood, Donors, Port-Harcourt, Metropolis.

\section{INTRODUCTION}

Blood transfusion worldwide is currently facing interesting challenges. A myriad of TTIs,HIV, HBV, HCV andVD, have provoked a greatly heightened emphasis on safety with inescapable implications for the complexity and cost of providing a transfusion service. The discovery that HIV, $\mathrm{HBV}$ and HCV could be transmitted through transfusion has heralded a new era in blood transfusion practice worldwide with emphasis on two fundamental objectives, safety and protection of human life(Diwan \& Mathur, 2012; WHO, 2012).
There are estimated 33 million people living with HIV/AIDS in the world and of these 23 million are in sub-Saharan Africa. Blood transfusion accounts for 5-10\% of the HIV infections in sub-Saharan Africa (Okoroiwu et al., 2018). Similarly, $12.5 \%$ of patients who received blood transfusion are at risk of post-transfusion hepatitis(Fasola \& Otegbayo, 2002).People in developing countries still face the risk of acquiring these infections because mandatory screening test are not carried out. Many countries still lack a national blood transfusion service despite some recent improvement in this important area. Human Immunodeficiency Virus, HBV, $\mathrm{HCV}$ and $\mathrm{VD}$ are of great concern as transfusion- 
transmissible infections because of their prolonged viraemia and carrier or latent state. They also cause fatal, acute, chronic and life-threatening disorders. These viral infections have emerged a global public health problem and a significant cause of mortality and morbidity in Nigeria and many parts of the world(Ejele et al., 2005).

The demand for blood is high and far outweighs its supply. Transfusion requirements and increasing demand for blood drives paid donors to donate more often than the required 12 weeks minimum interval which further complicates it. A significant number of the paid donor population has also been reported to be anaemic and further donation by such individuals without considering their baseline haemoglobin investigation could be harmful(Benedict et al., 2012)..Best practice as recommended by the World Health Organization ought to be put in place to be able to curb some of these issues.

There is a need to strictly regulate blood donation practices locally and the activities of those involved in blood banking. There is also a need to encourage non-remunerated voluntary blood donation practice which remains the gold standard in blood donation. However, voluntary donation is less than 25 $\%$ in Rivers State, Nigeria(Okoh et al., 2014) as a whole whereas in other States the rate is high. The aim of this study was to investigate TTIs among voluntary blood donors in Port-Harcourt Rivers State, Southern Nigeria.

\section{MATERIALS AND METHODS}

\subsection{Study Area}

This study was conducted in Port Harcourt.Port-Harcourt is a metropolitan city in the heart of the oil and gas industry in the Niger Delta region of Nigeria with a high influx of migrant workers from all parts of the world. The metropolis is an industrial centre with large number of multinational firms as well as other industrial concerns, particularly business related to the petroleum industry. It is the chief oilrefining city in Nigeria and has two main oil refineries that process around 210,000 barrels of crude oil daily. It is a port town that lies along the Bonny River (an eastern tributary of the River Niger), $66 \mathrm{~km}$ upstream from the Gulf of Guinea, with a population of 6,144,673 (Encyclopaedia Britannica). However, the city is characterized by low level of environmental sanitation, poor housing, lack of potable water and improper management of wastes especially in the indigenous core areas characterized by high density and low/middle income populations (Ayotamuno\& Gobo, 2004).

\subsection{Study Design}

ISSN: 2456-1878

https://dx.doi.org/10.22161/ijeab.61.32
The study was a cross sectional survey of transfusiontransmissible infections among voluntary blood donors of different age groups in Port-Harcourt metropolis. The research was conducted between March 2017 and June 2018.

\subsection{Study Population}

A total of two hundred 200 voluntary non-remunerated blood donors who consented, were recruited in the study. The blood specimens were collected over a period of six months.

\subsection{Ethical approval}

Ethical approval for this study was obtained from the ethical committee of the Ministry of Health, Government of Rivers State, Nigeria (MH/PRS/391/VOL.2/705).

\subsection{Consent}

Informed consent of the study participants were obtained after due sensitization. Donors' Confidentiality was assured.

\subsection{Criteria for selection of participants}

2.6.1 Inclusion criteria: included in the study were apparent healthy donors between 15 to 65 years of age, with no history of long-term medication use, with no history of blood transfusion within the last 3 months preceding the study, haemoglobin concentration $\geq 12.5 \mathrm{~g} / \mathrm{dL}$ prior to donation, willingness to give oral informed consent after counselling and non-menstruating or breast-feeding women.

2.6.2Exclusion criteria: excluded from the study were all blood donors who did not meet the inclusion criteria.

\subsection{Demographic Data of Participants}

The socio-demographic data of the blood donors, especially the age andgender were recorded.

\subsection{Blood Samples Collection}

Prior to collection of blood samples from the donors, a preblood donation sample was collected from each donor and sent to the Department of Pathology, River State University Teaching Hospital, Port-Harcourt for screening. Only donors who passed the inclusion criteria were bled, to avoid wastage of blood pints.Blood samples for the diagnosis of $\mathrm{HBV}$, HIV, HCV and VD infection were collected from all qualified study participants. The upper arm area of each donor was thoroughly cleaned and sterilized using cotton wool soaked in methylated spirit. Five millilitres of venous blood were obtained from the ante-cubital vein. About 2.5 $\mathrm{ml}$ of the blood was introduced into blood specimen bottle containing anticoagulant Ethylene Diamine Tetra-Acetic Acid (EDTA). The remaining $2.5 \mathrm{ml}$ was transferred into plain tubes without anticoagulant according to WHO standard method. The blood was allowed to clot and 
afterwards centrifuged. The serum samples were then aliquoted into a vial which was labelled and stored at $-20^{\circ} \mathrm{C}$ prior to testing. All blood donations were drawn manually and none was automated in this study. None of the blood donations were separated into components.

\subsubsection{Examination of Blood Samples for Venereal Disease Research Laboratory (VDRL), HBV and HCV}

The donor blood samples were screened for VDRL, Hepatitis B antigen (HBsAg) and HCV. Testing for HBV and HCV were based on chromatographic methods using test kits according to the manufacturers' instructions. All the reactive samples were repeated in duplicate before labelling them seropositive or seronegative. The VDRL test for antibodies to Treponema pallidum was conducted using the DiaSpot $^{\circledR}$ Rapid Detection Testing kits (ACON one-step insert rapid chromatographic immunoassay test strips). The test was performed according to the manufacturer's instructions.

\subsubsection{Examination of Blood Samples for HIV 1 and 2}

HIV test was done according to the national testing algorithm. Using the stored serum samples earlier collected from the participants, HIV screening was done with two kits as recommended by the World Health Organization(WHO, 2015). Determine ${ }^{\circledR}$ HIV-1/2 (5 Abbott Laboratories, IL, USA) was used for the test, while Uni-Gold ${ }^{\circledR} \mathrm{HIV}-1 / 2$ (Trinity Biotech, Dublin, Ireland) was used for the confirmatory test. The test was carried out by applying $50 \mu \mathrm{L}$ of the serum to the Sample Pad (marked by the arrow symbol) of the Test Unit and allowed to lay flat in the bench for 20 minutes, after which the result was read and interpreted based on the presence or absence of two pink/red

Table 1: Prevalence of TTIs among the study participants in Port Harcourt metropolis

\begin{tabular}{lllll}
\hline \multirow{2}{*}{ TTIs } & Number tested & \multicolumn{3}{c}{ Seropositive } \\
\cline { 3 - 5 } & & Positive males $(\%)$ & Positive females (\%) & Total (\%) \\
\hline HIV & 200 & $0(0)$ & $0(0)$ & $0(0)$ \\
VDRL & 200 & $0(0)$ & $2(1.0)$ & $2(1)$ \\
HBsAg & 200 & $5(2.5)$ & $3(1.5)$ & $8(4)$ \\
HCV & 200 & $0(0)$ & $1(0.5)$ & $1(0.5)$ \\
\hline Total & 200 & $5(2.5)$ & $6(3.0)$ & $11(5.5)$ \\
\hline
\end{tabular}

Of the 11 positive cases of other transfusion transmissible infections $9(81.82 \%)$ were in the age group $15-25$ years and $2(18.18 \%)$ were in the age group $26-35$ years. None in the age groups between 36 and 65 years had any blood transfusion transmissible infections. Also, of the 11 positive lines (Control line and $\mathrm{Ab}$ line). The Control line appears in the Control Area and the Ab line appears in the Lower Test Area of the Test Unit. The intensity of the $\mathrm{Ab}$ and Control lines may vary, however, any visible pink/red colour in both the Control and Lower Test Areas, regardless of intensity, is considered reactive. A Reactive test result means that HIV-1 and/or HIV-2 antibodies have been detected in the sample. The test result is therefore interpreted as preliminary positive for HIV-1 and/or HIV-2 antibodies.Since the serum sample was used for the test, the Chase Buffer was not added. As part of quality assurance measures, the test initiated within 2 hours after removing the protective foil cover from each Test Unit and results were not read after 30 minutes of adding the serum sample.

\subsection{Data Analysis}

The data collected was analysed using the Statistical Package for Social Sciences (SPSS) version 2.3. All the categorical variables were summarised percentages and used to evaluate descriptive statistics. Significant levels were measured at $95 \%$ CI with the levels of significance set at $5 \%$ probability value $(P>0.05)$.

\section{RESULTS}

Of the 200 participants examined, none tested positive for HIV 1 \&2. A total of $8(4.0 \%)$ were positive for HBSAg. Only $1(0.5 \%)$ was positive for $\mathrm{HCV}$ while $2(1.0 \%)$ were positive for VDRL. The prevalence of TTIs was higher in females $6(3.0 \%)$ than in males $5(2.5 \%)$. There was no significant differences in prevalence among genders $(P>$ $0.05)$ [Table 1]. 
Table 2: Prevalence of TTIs among the different age groups of study participants in Port Harcourt metropolis

\begin{tabular}{lllllll}
\hline Age groups (Years) & Number tested (\%) & \multicolumn{5}{c}{ Transfusion transmissible infections } \\
\cline { 2 - 6 } & & HIV $(\%)$ & VDRL $(\%)$ & HBSAg $(\%)$ & HCV (\%) & Total (\%) \\
\hline $15-25$ & $64(32.0)$ & $0(0)$ & $2(3.13)$ & $6(9.38)$ & $1(1.56)$ & $9(14.06)$ \\
$26-35$ & $86(43.0)$ & $0(0)$ & $0(0)$ & $2(25.0)$ & $0(0)$ & $2(2.38)$ \\
$36-45$ & $38(19.0)$ & $0(0)$ & $0(0)$ & $0(0)$ & $0(0)$ & $0(0)$ \\
$46-55$ & $9(4.5)$ & $0(0)$ & $0(0)$ & $0(0)$ & $0(0)$ & $0(0)$ \\
$56-65$ & $3(1.5)$ & $0(0)$ & $0(0)$ & $0(0)$ & $0(0)$ & $0(0)$ \\
\hline Total & 200 & $0(0)$ & $2(1)$ & $8(4)$ & $1(0.5)$ & 11 \\
\hline
\end{tabular}

\section{DISCUSSION}

In his study, the prevalence of HIV was found to be $0.0 \%$ which means that none of the blood donors had antibodies to human immunodeficiency virus detected by the testing method used. A similar study by Tiwari et al. (2008)reported $0.084 \%$ and $0.054 \%$ prevalence of HIV among voluntary non-remunerated blood donors using rapid test kits. This shows that the blood donors in the present study area were safe. But a contrary report by Dada et al., (2015)reveals that some of the apparently healthy blood donors in their study, were seropositive for HIV.For VDRL, the prevalence was found to be $1 \%$ in the present study, which compares favourably with another study(Ahmad et al., 2019).

A total of $4.0 \%$ were positive for HBsAg. Prevalence of HBV among blood donors differs. Another study carried out in South Eastern Nigeria shows that among healthy blood donors, $2.7 \%$ were seropositive of HBsAg(Dadaet al., 2015). The major route of HBV transmission is parenteral and it is most infective among blood-borne viruses in chronic carrier state and is associated with chronic liver disease, cirrhosis and Hepatocellular carcinoma.

For Hepatitis $\mathrm{C}$, the observed prevalence in this study was $0.5 \%$. This agrees with an earlier observation by Narayanasamy et al. (2015)which reported a similar prevalence of HCV in their study in India. Transmission of $\mathrm{HCV}$ is primarily through blood exposure and majority of the infected persons progress to chronic and chance of cirrhosis and hepatocellular carcinoma is more as compared to HBV. This study has once more reaffirmed that blood is one of the main sources of transmission of HBV, HCV and $\mathrm{VD}$, therefore donor selection is of paramount importance (Houghton, 2009).

\section{REFERENCES}

[1] Ahmad M., Saeed M., Hanif A., Waheed U., Arshad M., Ain N.U., Hussain S. (2019). Slump of Trends in Transfusion-Transmissible Infectious Diseases: Is Syphils Alarming in Pakistan? Global Journal of Transfusion Medicine, 2(2), 124-129. https://doi.org/10.4103/GJTM.GJTM

[2] Ayotamuno J.M. \& Gobo A.E. (2004). Municipal solid waste management in Port Harcourt, Nigeria: Obstacles and prospects. Management of Environmental Quality: $\quad$ An International Journal, $\quad$ 15(4), 389-398. https://doi.org/10.1108/14777830410540135

[3] Benedict N., Augustina A. \& Nosakhare B. (2012). Blood Donation in Nigeria: Standard of the Donated Blood. Journal of Laboratory Physicians, 4(2), 94. https://doi.org/10.4103/0974-2727.105589

[4] Dada O.M., Okorafor K.S., Eze T., \& Onwurah O.W. (2015). Sero-Prevalence of Major Transfusion-Transmitted Infections (TTIs) Among Blood Donors of Nnewi, Southeastern Nigeria. South American Journal of Public Health, 3(4), 1-6.

[5] Diwan R. \& Mathur M. (2012). Incidence and pattern of transfusion transmitted infection in voluntary donors in a teaching hospital "A four year retrospective study" Abstract: Introduction: Material and methods: Results: Journal of Pharmaceutical and Biomedical Sciences, 22(1), 1-4.

[6] Ejele O.A., Erhabor O., \& Nwauche C.A. (2005).The risk of transfussion-transmissible viral infections in the Niger-Delta area of Nigeria.Sahel Medical Journal, 8(1), 16-19.

[7] Fasola F.A.\& Otegbayo I.A. (2002). Post-transfusion viral hepatitis in sickle cell anemia: retrospective prospective analysis. Nigeria Journal of Clinical Practice, 5(1), 16-19.

[8] Houghton M. (2009). Discovery of the hepatitis C virus.Liver International, 29(1), 82-88. https://doi.org/10.1111/j.14783231.2008.01925.x

[9] Narayanasamy K., Annasamy C, Ramalingam S. \& Elumalai S. (2015). Study of Hepatitis B and C Virus Infection in Urban and rural Population of Tamil Nadu, India. 
International Journal of Current Microbiology and Applied Sciences, 4(6), 443-451.

[10] Okoh D.A, Omunakwe H.E. \& Iyalla C. (2014).Trends in transfusion-transmissible infections in potential donors in a specialist hospital in Rivers State.ISBT Science Series, 9(2), 334-338. https://doi.org/10.1111/voxs.12156

[11] Okoroiwu H.U., Okafor I.M., Asemota E.A., \& Okpokam D.C. (2018). Seroprevalence of transfusion-transmissible infections (HBV, HCV, syphilis and HIV) among prospective blood donors in a tertiary health care facility in Calabar, Nigeria; An eleven years evaluation. BMC Public Health, 18(1), 1-8. https://doi.org/10.1186/s12889-018-5555-x

[12] Tiwari B., Ghimire P., Karki S. \& Rajkarnikar M. (2008). Seroprevalence of human immunodeficiency virus in Nepalese blood donors: A study from three regional blood transfusion services. Asian Journal of Transfusion Science, 2(2), 66.https://doi.org/10.4103/0973-6247.42663

[13] WHO (2012). Blood donor selection: guidelines on assessing donor suitability for blood donation. World Health Organization. Geneva. https://doi.org/10.1016/S10523359(03)00051-6.

[14] WHO (2015). HIV assays: Laboratory performance and other operational characteristics. WHO Library Cataloguing. 